\title{
HUBUNGAN PERILAKU CARING PERAWAT DENGAN TINGKAT KEPUASAN PASIEN DI RUMAH SAKIT PERMATA BUNDA MEDAN TAHUN 2019
}

\author{
Sukma Yunita, Panri Hariadi \\ Prodi Studi D3 Keperawatan, STIKes Rs Haji Medan \\ E-mail : sukmayunita28@gmail.com, \\ Prodi Studi D3 Keperawatan, STIKes Rs Haji Medan \\ E-mail : pandrihariadi97@gmail.com
}

\begin{abstract}
Quality health services are services that can satisfy every service user, nurses in providing services are manifested in a caring attitude. Nurse caring behavior is one of the determinants of patient satisfaction. This type of research uses descriptive correlation and the design of this study uses a cross sectional design, the population in this study is all patients treated in the emerald II room as many as 420 people. The sampling technique was purposive sampling. Data analysis was performed by univariate and bivariate using chi square tests. The results of the study that the majority of caring behavior is always as many as 37 respondents $(88.1 \%)$, the majority of patient satisfaction is very satisfied as many as 37 respondents $(88.1 \%)$. Statistical test results with chi square obtained value of $0.000<0.05$ means that there is a relationship between caring behavior with the level of patient satisfaction at the Permata Bunda General Hospital in 2019. The conclusion of the study is the relationship between caring behavior with the level of patient satisfaction at the Permata Bunda General Hospital 2019. It is recommended for nurses to improve the quality of nursing service delivery of nursing services especially nurses caring behavior with patient satisfaction so that it can improve the quality of nursing services and the quality of the hospital is getting better.
\end{abstract}

Keywords : Caring Behavior, Patient Satisfaction

\begin{abstract}
Abstrak
Pelayanan kesehatan yang bermutu adalah pelayanan yang dapat memuaskan setiap pemakai jasa layanan, perawat dalam memberikan pelayanan diwujudkan dalam sikap caring. Perilaku caring perawat merupakan salah faktor penentu kepuasan pasien..Jenis penelitian menggunakan deskriptif korelasi dan desain penelitian ini menggunakan desain cross sectional, populasi dalam penelitian ini adalah seluruh pasien yang dirawat di ruang zamrud II inap sebanyak 420 orang. Teknik pengambilan sampel dengan purposive sampling. Analisa data dilakukan dengan univariat dan bivariat menggunakan uji chi square. Hasil penelitian bahwa perilaku caring mayoritas selalu sebanyak 37 responden $(88,1 \%)$, kepuasan pasien mayoritas sangat puas sebanyak 37 responden $(88,1 \%)$. Hasil uji statistik dengan chi square diperoleh nilai value sebesar $0.000<0,05$ artinya terdapat Hubungan perilaku caring dengan tingkat kepuasan pasien di Rumah Sakit Umum Permata Bunda tahun 2019. Kesimpulan penelitian terdapat Hubungan perilaku caring dengan tingkat kepuasan pasien di Rumah Sakit Umum Permata Bunda Tahun 2019. Disarankan untuk perawat untuk meningkatkan kualitas dalam pemberian pelayanan keperawatan pemberian pelayanan keperawatan khususnya perilaku caring perawat dengan kepuasan pasien sehingga dapat meningkatkan mutu pelayanan keperawatan serta kualitas Rumah Sakit semakin baik.
\end{abstract}

Kata Kunci : Perilaku Caring, Kepuasan Pasien 


\section{PENDAHULUAN}

Rumah sakit merupakan sarana pelayanan kesehatan yang mempunyai fungsi utama menyediakan dan menyelenggarakan upaya kesehatan yang bersifat penyembuhan penyakit (kuratif) dan pemulihan kesehatan (rehabilitatif) baik fisik maupun psikososial yang dilakukan secara terpadu (Ilyas, 1999) dalam (Ahituta, 2009). Mutu pelayanan keperawatan sangat mempengaruhi kualitas pelayanan kesehatan, bahkan menjadi salah satu faktor penentu citra institusi pelayanan kesehatan seperti rumah sakit. Hal ini terjadi karena keperawatan merupakan kelompok profesi dengan jumlah terbanyak, paling depan dan terdekat dengan penderitaan orang lain, kesakitan, kesengsaraan yang dialami masyarakat. Salah satu indikator dari mutu pelayanan keperawatan yaitu apakah pelayanan keperawatan yang diberikan memuaskan pasien atau tidak (Nursalam, 2011).

Gillies (1978 dalam (Meyer \& Pallas, 2010) menjelaskan bahwa keberhasilan memberikan pelayanan keperawatan merupakan cerminan utama pelayanan kesehatan di rumah sakit. Pelayanan profesional oleh perawat dapat dilakukan oleh perawat dengan memperlihatkan perilaku caring. Perilaku Caring perawat sangat penting dalam memenuhi kepuasan pasien, hal ini menjadi salah satu indikator kualitas pelayanan di sebuah rumah sakit. Hal ini merupakan sentral praktik keperawatan, juga merupakan suatu cara pendekatan yang dinamis, dimana perawat bekerja untuk lebih meningkatkan kepeduliannya terhadap pasien. Perawat adalah orang yang menjadi salah satu kunci dalam memenuhi kepuasan pasien. Oleh karena itu, perilaku caring perawat dapat memberikan pengaruh dalam pelayanan yang berkualitas kepada pasien (Prompahakul, Nilmanat, \& Kongsuwan, 2011).

Rahayu (2011) dalam penelitiannya tentang faktor-faktor yang berhubungan dengan sikap caring perawat yang dipersiapkan perawat pelaksana di Ruang Rawat Inap RSUP Persahabatan Jakarta, menemukan bahwa $51,9 \%$ perawat bersikap caring dan $48,1 \%$ kurang bersikap caring. Menurut Rahayu hal ini merupakan masalah potensial yang dapat mempengaruhi kepuasan klien karena responden (perawat) yang kurang caring mempunyai presentase yang relatif besar (Rahayu, 2011). Husein (2006) dalam (Rahayu, 2011) mendapatkan bahwa $90 \%$ pasien mengatakan tidak merasa nyaman berbicara dengan perawat, $84 \%$ dari jumlah tersebut memiliki pengalaman negatif karena perawat tidak memperhatikan kebutuhan pasien terutama di malam hari.

Kepuasan pasien merupakan faktor yang sangat penting untuk mengevaluasi mutu pelayanan keperawatan yang dilakukan oleh perawat di rumah sakit dan perilaku caring perawat adalah salah satu aspek yang berhubungan dengan pelayanan keperawatan, karena caring mencakup hubungan antar manusia dan berpengaruh terhadap mutu pelayanan dan kepuasan pasien. Kepuasan pasien dapat dinilai dari beberpa dimensi yang meliputi: tangibles, reliability, responsiveness, assurance dan emphaty (Nursalam, 2015). Hal ini didukung oleh penelitian Shirley dkk., (2012) tentang tingkat kepuasan pasien dibangsal orthopedi dengan kepedulian perawat di Rumah Sakit Universitas Sains Malaysia, didapatkan bahwa $82,7 \%$ merasa puas dengan pelayanan perawat seperti menghargai pasien, tenang, lemah lembut, perhatian, kasih sayang dan empati.

Hasil penelitian Wicaksono dan Prawesti (2012), terhadap pasien di kelas 2 dan kelas 3A Instalansi Rawat Inap Rumah Sakit Baptis Kediri dengan sampel 96 responden. Variabel bebasnya adalah kiat caring perawat. Variabel terikatnya adalah kualitas pelayanan keperawatan. Data dikumpulkan melalui kuesioner terstruktur. Data analisa menggunakan Uji Spearman Rho dengan tingkat signifikansi 0,05 . Kiat caring perawat berhubungan dengan kualitas pelayanan keperawatan dengan $p=0,000$ dan $r=0,675$ dan merupakan hubungan positif. Kiat caring perawat yang baik dapat meningkatkan mutu asuhan keperawatan di Rumah Sakit Baptis Kediri. Faktanya banyak perawat yang belum mencerminkan perilaku caring dalam merawat pasien. Hasil beberapa penelitian didapatkan bahwa : 1). Penelitian di RSU dr. H. Koesnadi Bondowoso, $50 \%$ perawat belum 
mengaplikasikan caring dan 43,5\% memiliki pengetahuan kurang tentang caring (Prabowo, Anisa dan Dodi, 2014), 2). Penelitian Khairina, Wiwi dan Dian (2011) di RSUD Bandung, didapatkan 52,64\% perawat belum memiliki perilaku caring.

\section{METODE PENELITIAN}

Desain penelitian adalah seluruh rencana penelitian yang disusun sedemikan rupa sehingga peneliti dapat memperoleh suatu jawaban terhadap pertanyaan penelitian. Desain Penelitian yang digunakan yaitu cross sectional, yaitu suatu penelitian yang mempelajari dinamika korelasi antara faktorfaktor resiko dengan efek, dengan cara pendekatan, observasi atau pengumpulan dan sekaligus pada suatu saat. Artinya variabel sebab atau resiko dan akibat atau kasus yang terjadi pada objek penelitian hanya diukur secara simultan, sesaat atau sekali saja dalam waktu yang bersamaan pada saat pemeriksaan. (Setiadi,2013)

Populasi dalam penelitian ini adalah seluruh pasien yang dirawat inap di ruangan zamrud II yang dalam satu bulan rata-rata pasiennya berjumlah 420 orang. Tehnik dalam pengambilan sampel dalam penelitian ini adalah purposive sample, disini peneliti menggunakan rumus Arikunto (20013), yang menjelaskan bahwa apabila populasi lebih dari 100 maka besar sampel dapat diambil antara $10-15 \%$ atau $20-25 \%$ atau lebih tergantung situasinya, maka sampelnya diambil $10 \%$ sehubungan dengan populasi penelitian sebesar 420 orang. Jadi sampel dalam penelitian ini sebamyak 42 orang.

Instrumen dalam penelitian ini berupa kuesioner, dimana kuesioner tersebut diambil dari kuesioner penelitian rahmad gurusinaga tahun 2013. Instrument penelitian ini terdiri dari 68 pertanyaan yang masing masing variabel terdiri dari 42 pertanyaan untuk pernyataan perilaku caring perawat dan 26 pertanyaan untuk pernyataan kepuasan pasien.

Alat analisis yang digunakan adalah korelasi Chi Square. Untuk menentukan kesimpulan adanya hubungan antara perilaku caring perawat dengan kepuasan pasien digunakan pendekatan probability $(\rho)$, yaitu membandingkan nilai $p$ value dengan derajat kemaknaan $(\alpha)$ penelitian.

\section{HASIL DAN PEMBAHASAN}

\section{Data demografi}

Tabel 4.1 Distribusi Frekuensi Berdasarkan Karakteristik Responden

\begin{tabular}{|c|c|c|c|}
\hline $\begin{array}{l}\mathrm{N} \\
\mathrm{o}\end{array}$ & $\begin{array}{c}\text { Karakteristik } \\
\text { Responden }\end{array}$ & $\begin{array}{c}\text { Jumlah } \\
\mathrm{N}\end{array}$ & Persentase $(\%)$ \\
\hline \multirow[t]{9}{*}{1.} & Umur & & \\
\hline & $15-25$ & 7 & 16,7 \\
\hline & $26-35$ & 3 & 7,1 \\
\hline & $36-45$ & 10 & 23,8 \\
\hline & $46-55$ & 9 & 21,4 \\
\hline & $56-65$ & 8 & 19 \\
\hline & $66-75$ & 3 & 7,1 \\
\hline & $76-85$ & 2 & 4,8 \\
\hline & Total & 42 & 100 \\
\hline \multirow[t]{4}{*}{2.} & $\begin{array}{l}\text { Jenis } \\
\text { kelamin }\end{array}$ & & \\
\hline & Perempuan & 30 & 71,4 \\
\hline & Laki-laki & 12 & 28,6 \\
\hline & Total & 42 & 100 \\
\hline \multirow[t]{6}{*}{3.} & Pendidikan & & \\
\hline & SD & 5 & 11,9 \\
\hline & SLTP & 12 & 28,6 \\
\hline & SLTA & 20 & 47,6 \\
\hline & Sarjana & 5 & 11,9 \\
\hline & Total & 42 & 100 \\
\hline \multirow[t]{5}{*}{4.} & $\begin{array}{l}\text { Status } \\
\text { pernikahan }\end{array}$ & & \\
\hline & Menikah & 30 & 71,4 \\
\hline & Belum & 10 & 23,8 \\
\hline & $\begin{array}{l}\text { menikah } \\
\text { Lainya }\end{array}$ & 2 & 4,8 \\
\hline & Total & 42 & 100 \\
\hline
\end{tabular}

\section{Analisa univariat}

Berdasarkan tabel 4.1 diatas diketahui responden penelitian berusia 36-45 sebanyak 10 orang $(23,8 \%)$, jenis kelamin perempuan sebanyak 30 orang $(71,4 \%)$, berpendidikan SLTA sebanyak 20 orang $(47,6 \%)$, status pernikahan sudah menikah sebanyak 30 orang $(71,4 \%)$. 
Tabel 4.2 Distribusi frekuensi perilaku caring perawat di Rumah Sakit Umum Permata Bunda Tahun 2019

\begin{tabular}{ccc}
\hline $\begin{array}{c}\text { Perilaku } \\
\text { caring }\end{array}$ & Frekuensi & Persentase \\
\hline Kurang baik & 5 & 11,9 \\
Sangat baik & 37 & 88,1 \\
\hline Total & 42 & 100 \\
\hline
\end{tabular}

Berdasarkan tabel 4.2 diatas diketahui, bahwa frekuensi perilaku caring di Rumah Sakit Umum Permata Bunda Tahun 2019 mayoritas sangat baik sebanyak 37 orang $(88,1 \%)$.

Tabel 4.3 Distribusi frekuensi kepuasan pasien di Rumah Sakit Umum Permata Bunda Tahun 2019

\begin{tabular}{ccc}
\hline $\begin{array}{c}\text { Kepuasan } \\
\text { pasien }\end{array}$ & Frekuensi & Persentase \\
\hline Kurang puas & 5 & 11,9 \\
Sangat puas & 37 & 88,1 \\
\hline Total & 42 & 100 \\
\hline
\end{tabular}

Berdasarkan tabel 4.3 diatas diketahui, bahwa frekuensi kepuasan pasien di Rumah Sakit UmumPermata Bunda Tahun 2019 mayoritas sangat puas sebanyak 37 orang $(88,1 \%)$.

\section{Analisa bivariat}

Tabel 4.4 Hasil analisa hubungan perilaku caring dengan kepuasan pasien di Rumah Sakit Umum Permata Bunda Tahun 2019

\begin{tabular}{|c|c|c|c|c|c|c|c|c|}
\hline \multirow{3}{*}{$\begin{array}{c}\text { Prilaku } \\
\text { Caring }\end{array}$} & \multicolumn{8}{|c|}{$\begin{array}{c}\text { Kepuasan } \\
\text { Pasien }\end{array}$} \\
\hline & \multicolumn{2}{|c|}{$\begin{array}{l}\text { Tidak } \\
\text { Puas }\end{array}$} & \multicolumn{2}{|c|}{$\begin{array}{c}\text { Sangat } \\
\text { Puas }\end{array}$} & \multicolumn{2}{|c|}{ Total } & \multirow[t]{2}{*}{$X^{2}$} & \multirow[t]{2}{*}{$\begin{array}{c}\mathrm{P} \\
\text { Value }\end{array}$} \\
\hline & $\mathrm{F}$ & $\%$ & $\mathrm{~F}$ & $\%$ & $\mathrm{~F}$ & $\%$ & & \\
\hline $\begin{array}{c}\text { Kurang } \\
\text { Baik }\end{array}$ & 5 & 11,9 & 0 & 0 & 5 & 11,9 & $\begin{array}{c}33, \\
006\end{array}$ & ,000 \\
\hline $\begin{array}{c}\text { Sangat } \\
\text { Baik }\end{array}$ & 0 & 0 & 37 & 88,1 & 37 & 88,1 & & \\
\hline Total & 5 & 11,9 & 37 & 88,1 & 42 & 100 & & \\
\hline
\end{tabular}

Berdasarkan tabel 4.4 diatas dapat diketahui bahwa 37 orang $(88,1 \%)$ responden yang memiliki perilaku caring yang sangat baik, 5 orang $(11,9 \%)$ responden yang memiliki perilaku caring yang kurang baik, dan 37 orang $(88,1 \%)$ responden yang memiliki kepuasan pasien yang sangat puas, 5 orang $(11,9 \%)$ yang memiliki kepuasan pasien yang kurang puas. Hasil uji statistik dengan chi square menunjukkan bahwa ada hubungan perilaku caring dengan kepuasan pasien di Rumah sakit umum Permata Bunda tahun 2019 dengan nilai $\mathrm{P}$ value sebesar $0.000(<0,05)$, artinya bahwa ada hubungan perilaku caring dengan kepuasan pasien di Rumah sakit umum Permata Bunda tahun 2019.

\section{PEMBAHASAN}

Hasil penelitian perilaku caring dengan kepuasan pasien di Rumah Sakit Umum Permata Bunda Tahun 2019 mayoritas selalu. Hal ini terlihat dari hasil kuesioner perilaku caring mayoritas selalu. Hal ini didapatkan karena Rumah Sakit Umum Permata Bunda mengedepankan pelayanan terhadap pasien sebagai kelangsungan Rumah Sakit kedepannya dan manajemen Rumah Sakit Umum Permata Bunda senantiasa menggelorakan landasan pelayanan terbaik dan ramah (rasional, aman, manusiawi, aktif, dan harmonis) dalam melayani pasien.

Perawat merupakan bagian dari dari tim pelayanan kesehatan di Rumah Sakit, perilaku caring yang ditunjukkan perawat dalam memberikan pelayanan menjadi salah satu indikator mutu pelayanan. Semakin baik perilaku caring perawat dalam memberikan pelayanan asuhan keperawatan, maka pasien atau keluarga semakin senang dalam menerima pelayanan, berarti hubungan teraupetik perawat-klien semakin terbina (Abdul, 2012).

Hal ini sejalan dengan teori Nursalam (2014) yang mengatakan Caring sebagai bentuk memberikan perhatian kepada orang lain, berpusat pada orang, menghormati orang harga diri dan kemanusiaan, komitmen untuk mencegah terjadinya status kesehatan yang memburuk, memberikan perhatian dan menghormati orang lain.

Hal ini sejalan dengan teori (Duffy, 2009 dalam Eny Kusmiran, 2015) yang berpendapat Caring merupakan tindakan dengan sikap peduli kepada orang, menenangkan memberikan perlindungan terhadap kerugian, memelihara martabat orang lain. Perilaku caring dapat dinyatakan sebagai 
suatu perasaan untuk memberikan keamanan, perubahan perilaku dan bekerja sesuai standar.

Caring adalah suatu proses yang disegaja yang membuthkan kesadaran diri, proses memilih, pengetahuan dan keterampilan khusus serta mempertimbangkan waktu (Waston, 2008 dalam Eny Kusmiran, 2015)

Asumsi peneliti tentang perilaku caring perawat mayoritas perilaku selalu. Hal ini disebabkan karena Rumah Sakit Umum Permata Bunda mengedepankan pelayanan terhadap pasien sebagai kelangsungan rumah Sakit kedepannya dan manajemen Rumah Sakit Umum Permata Bunda senantiasa menggelorakan landasan pelayanan terbaik dan ramah (rasional, aman, manusiawi, aktif, dan harmonis) dalam melayani pasien. Perawat di Rumah Sakit Permata Bunda sadar tugasnya sebagai provider dimana pelayanan yang diberikan perawat harus dapat dirasakan dan memberikan dampak yang positif terhadap pasien sebagai custumer (pelanggan) pelayanan di Rumah Sakit.

Hasil distribusi frekuensi kepuasan pasien di Rumah Sakit Umum Permata Bunda Tahun 2019 mayoritas sangat puas.

Hal ini terlihat dari hasil kuesioner kepuasan pasien dapat diketahui mayoritas sangat puas. Hal ini didapatkan karena di Rumah Sakit Umum Permata Bunda memiliki standart kepuasan pasien dengan IKP $>70 \%$. Untuk mencapai standart tersebut manajemen Rumah Sakit Umum Permata Bunda memiliki visi menjadi Rumah Sakit dengan pelayanan yang bermutu, aman, terjangkau dan berazaskan kekeluargaan, dan memiliki misi ( menyelenggarakan pelayanan prima, meningkatkan kualitas seluruh aspek pelayanan, meningkatkan pendidikan pelatihan tenaga kesehatan, pengembangan sarana dan prasarana sera peralatan medis dan penunjang medis) dan senantiasa menggelorakan landasan pelayanan terbaik dan ramah (rasional, aman, manusiawi, aktif, dan harmonis) dalam melayani pasien. Selain membangun sprit tersebut, juga dilakukan pelatihan-pelatihan yang menunjang karyawan untuk tampil/bersikap profesional, ramah dan peduli kepada pasien, sehingga akan memberikan kesan positif pada pelanggan kemudian terbentuknya adanya ikatan bathin yang akhirnya membuat pasien/pelanggan merasa puas.

Hal ini sesuai dengan pandapat Triwibowo Soedjas (2014) yang menyatakan bahwa hanya pelayanan yang luar biasa yang membuat pelanggan puas dan terkesan. Pelayanan luar biasa tersebut bisa dirasakan saat momen-momen interaksi yang dapat membentuk ikatan bathin yang disebut dengan moment of truth.

Hasil penelitian ini juga menunjukkan pelaksanaan asuhan keperawatan yang dilakukan perawat mendapatkan penilaian yang tinggi. Hasil penelitian ini sependapat dengan Suryawati, Dharminto, Zahroh (2014) dalam penyusunan indikator kepuasan pasien/pelanggan rawat inap Rumah Sakit di Provinsi jawa tengah yang mengatakan mayoritas pelanggan Rumah Sakit puas dengan pelayanan yang telah diterima, dengan persentase terendah pada kondisi fisik ruang perawatan pasien dan tertinggi pelayanan yang diberikan. Hanya saja untuk penelitian di Rumah Sakit Umum Permata Bunda, persentase tertinggi pada Dimensi Reliability (kehandalan) sebesar $90 \%$ yaitu alur pelayanan, perawat segera datang ketika mendengar keluhan, dan pasien merasakan kenyamanan ketika perawat melakukan tindakan.

Hal ini didukung oleh pendapat Nursalam (2014) yang mengatakan bahwa kepuasan pasien/pelanggan adalah perasaan senang atau bahwa produk/ jasa yang diterima sesuai/ melebihi harapan pelanggan. Selain itu juga mendukung pendapat dari Fais (2014) yang menyatakan kepuasan pasien adalah evaluasi positif dari dimensi pelayanan yang beragam. Pelayanan yang dievaluasi dapat berupa sebagian kecil dari pelayanan, semua jenis pelayanan untuk menyembuhkan seorang pasien sampai dengan sistem pelayanan secara menyeluruh di dalam Rumah Sakit.

Asumsi peneliti tentang kepuasan pasien mayoritas sangat puas. Hal ini disebabkan karena Rumah Sakit Umum Permata Bunda memiliki standart kepuasan pasien dengan IKP $>70 \%$. Untuk mencapai standart tersebut manajemen Rumah Sakit 
Umum Permata Bunda memiliki visi menjadi Rumah Sakit dengan pelayanan yang bermutu, aman, terjangkau dan berazaskan kekeluargaan, dan memiliki misi ( menyelenggarakan pelayanan prima, meningkatkan kualitas seluruh aspek pelayanan, meningkatkan pendidikan pelatihan tenaga kesehatan, pengembangan sarana dan prasarana sera peralatan medis dan penunjang medis) dan senantiasa menggelorakan landasan pelayanan terbaik dan ramah (rasional, aman, manusiawi, aktif, dan harmonis) dalam melayani pasien. Selain membangun sprit tersebut, juga dilakukan pelatihan-pelatihan yang menunjang karyawan untuk tampil/bersikap profesional, ramah dan peduli kepada pasien,senantiasa menggelorakan landasan pelayanan yang cepat, motto (senyum, sentuh, sapa, jujur, tulus, ikhlas dan kerja-kerja-kerja) dalam melayani pasien.

Berdasarkan hasil penelitian diatas didapatkan dari sampel 42 orang didapatkan hasil yaitu :Hasil penelitian ini menunjukkan bahwa 37 orang $(88,1 \%)$ responden yang memiliki perilaku caring sangat baik, maka 37 orang $(88,1 \%)$ responden yang memiliki kepuasan pasien yang sangat puas, 5 orang $(11,9 \%)$ responden yang memiliki perilaku caring yang kurang baik, maka 5 orang $(11,9$ $\%$ ) yang memiliki kepuasan pasien yang kurang puas. Hasil uji statistik dengan chi square menunjukkan bahwa ada hubungan perilaku caring dengan kepuasan pasien di Rumah sakit umum Permata Bunda tahun 2019 dengan nilai $\mathrm{P}$ value sebesar $0.000(<0,05)$, artinya bahwa ada hubungan perilaku caring dengan kepuasan pasien di Rumah sakit umum Permata Bunda tahun 2019.

Hasil penelitian ini didukung oleh penelitian Asriani (2012) yaitu hubungan antara persepsi pasien tentang perilaku caring perawat dengan tingkat kepuasan pasien di Instalasi Rawat Inap Paviliun Garuda VIP B RSUD Dr. Kariadi Semarang dengan hasil bahwa $68 \%$ pasien sangat puas dengan sejalan dengan perilaku caring perawat. Kemampuan perawat dengan memberikan pelayanan yang baik, dan menciptakan komunikasi yang menyenangkan terhadap pasien merupakan faktor penyebab kepuasan pasien yang akan dirasakan oleh pasien. Hal ini didukung oleh Ilkaffah dan Harniah (2017) dalam penelitiannya juga mendapatkan data adanya hubungan signifikan antara hubungan perilaku caring dengan kepuasan pasiendi Ruang Rawat inap Private Care Centre RSUP Dr. wahudin Sudirohosudo Makassar dengan nilai $\mathrm{P}=0,006$.

Hasil penelitian ini juga sesuai dengan teori yang dikemukakan oleh Nursalam (2014) Caring sebagai bentuk memberikan perhatian kepada orang lain, berpusat pada orang, menghormati orang harga diri dan kemanusiaan, komitmen untuk mencegah terjadinya status kesehatan yang memburuk, memberikan perhatian dan menghormati orang lain.

Hal ini didukung oleh AbuRuz et al (2015) mengatakan caring adalah perhatian perawat dengan sepenuh hati terhadap pasien, kepedulian, empati, komunikasi yang lemah lembut dan rasa kasih sayang perawat terhadap pasien akan membentuk hubungan perawatklien yang teraupetik.

Dari beberapa teori dan hasil penelitian tentang perilaku caring perawat dengan kepuasan pasien sangat erat hubunganya karena perlakuan perawat sebagai provider dimana pelayanan perawat harus dapat dirasakan dan member dampak yang positif terhadap pasien sebagai pelanggan pelayanan di Rumah Sakit. Kepuasan pasien adalah keluaran layanan kesehatan dengan demikian kepuasan pasien merupakan salah satu tujuan dari peningkatan layanan kesehatan (Dienemann, 2013).

Asumsi peneliti adanya hubungan antara perilaku caring perawat dengan kepuasan pasien di Rumah Sakit Umum Permata Bunda Tahun 2019 dikarenakan Rumah Sakit tersebut melakukan pelayanan kepada pasien dengan maksimal sehingga pasien merasa sangat puas.

\section{KESIMPULAN}

Dari hasil penelitian dan pembahasan tentang hubungan perilaku caring perawat dengan kepuasan pasien di Rumah Sakit Umum Permata Bunda tahun 2019 dapat ditarik kesimpulan sebagai berikut: 
1. Distribusi perilaku caring perawat di Rumah Sakit Umum Permata Bunda tahun 2019 mayoritas selalu.

2. Distribusi kepuasan pasien di Rumah Sakit Umum Permata Bunda tahun 2019 mayoritas sangat puas.

3. Ada hubungan perilaku caring perawat dengan kepuasan pasien di Rumah Sakit Umum Permata Bunda tahun 2019.

\section{SARAN}

Diharapkan bagi tempat penelitian agar dapat meningkatkan kualitas dalam pemberian pelayanan keperawatan khususnya perilaku caring perawat dengan kepuasan pasien sehingga dapat meningkatkan mutu pelayanan keperawatan serta kualitas Rumah Sakit semakin baik.

Diharapkan dapat menjadikan hasil penelitian ini sebagai referensi dan acuan yang ingin mengambil kasus tentang perilaku caring perawat dengan kepuasan pasien. Dan menggali seta mengembangkan perilaku caring dengan kepuasan pasien dalam penerapan ilmu dan konsep keperawatan.

Diharapkan untuk peneliti selanjutnya agar dapat mengembangkan penelitian ini, mengkaji lebih dalam, bukan hanya perilaku caring perawat saja namun kemungkinan faktor-faktor lain yang dapat mempengaruhi kepuasan pasien dengan mengembangkan variabel penelitian.

\section{DAFTAR PUSTAKA}

Abdul, Ariyanti Saleh, Elly L. Sujattar. Hubungan Perilaku Caring Perawat Dengan Tingkat Kepuasan Pasien Rawat Inap Rumah Sakit. Jurnal Universias Hasanuddin

Adityia Bastiansyah, Niken Sukesi, Wulandari M. Pengaruh Tingkat Kepuasan Perawat Terhadap Perilaku Caring Di Ruang Rawat Inap Rsud Kartini Jepara. Jurnal Universitas Muhammadiyah Semarang.

Arianti, Tutu April dan Nur Aini. 2018. Perilaku Caring Perawat Terhadap
Kepuasan Pasien Rawat Inap Pada Pelayanan Keperawatan. Jurnal Universitas Muhammadiyah Malang. Tahun 2018. Volume 9 Nomor 1, : 2443-0900

Arikunto, Suharsimi. 2014. Prosedur Penelitian Suatu Pendekatan Praktik. Jakarta : Rineka Cipta.

Ilkafah dan Harniah. 2017. Perilaku Caring Perawat Dengan Kepuasan Pasien Di Ruang Rawat Inapprivate Care Centre RSUP Dr Wahidin Sudirohusodo Makassar. Jurnal Universitas Hasanuddin. Tahun 2017. Volume 8 Nomor 2, : 2443-0900.

Juwariyah, Titik dan Nanang Bagus Witjayanto Joyo. 2014. Hubungan Perilaku Caring Perawat Dengan Tingkat Kepuasaan Pasien Di Poli Vct Rsud Gambiran Kota Kediri Berdasarkan Teori Watson. Jurnal Ners Dan Kebidanan. Tahun 2014. Volume 1 Nomor 3.

Kusmiran, Eny. 2015. Soft Skills Caring Dalam Pelayanan Keperawatan. Jakarta : $\mathrm{Cv}$ Trans Info Media.

Morrison, Paul dan Philip Burnard. Caring and Communicating Hubungan Interpersonal Dalam Keperawatan. Jakarta : Buku Kedokteran EGC.

Notoadmjo, S. 2010. Metode penelitian kesehatan. Jakarta : PT Rhineka Cipta.

Nursalam, 2013. Manajemen Keperawatan Aplikasi dan Praktik Keperawatan Profesional. Jakarta : Salemba Medika.

2014. Manajemen Keperawatan : Aplikasi dalam praktik keperawatan profesional. Edisi 4. Jakarta : Salemba Medika.

2015. Manajemen Keperawatan : Aplikasi dalam praktik keperawatan profesional. Edisi 5. Jakarta : Salemba Medika. 
Setiadi. 2007. Konsep Dan Penulisan Riset Keperawatan. Yogyakarta : Graha Ilmu.

Yasmini, Widjijati., Rinami., Santi Purwasih., Wiwit Sersanti., Hanum Lavisa, Neno Ivon. Hubungan Caring Perawat Pelaksana Dengan Kepuasan Pasien Di Ruang Rawat Inap Di Smc Rs Telogorejo Semarang. Jurnal Stikes Telogorejo Semarang. 